\title{
NATURAL GAS HEATING IN SERBIAN SETTLEMENTS ACCORDING TO URBANITY PARAMETERS *
}

\author{
$U D C 697.245: 711.42(083.74)(497.11)(045)=111$
}

\section{Dejan Brkić}

\author{
University of Belgrade, Faculty of Mining and Geology, \\ Department of Petroleum Engineering, Belgrade, Serbia \\ E-mail: dejanrgf@tesla.rcub.bg.ac.rs
}

\begin{abstract}
Natural gas can be directly used for heating of flats by gas distribution system. Indirectly, heating power plant can disburse natural gas and deliver hot water or steam for heating of flats. Decision of optimal way for gas heating usage is done based on spatial disposal of building, number and size of buildings in settlement, etc. Optimal solution, between gas distribution and district heating system (local or district heating by natural gas), can be done according to methodology (model approach) shown in this paper. According to variety of Serbian settlements (in density, size and layout of buildings) model which has ability to represent their different characteristics is formed. This model could be simple and useful tool for initial decision about energy supply system.
\end{abstract}

Key words: Natural Gas, Urbanism, Gas Distribution, District Heating

\section{INTRODUCTION}

When we talk about energy consumption of a city, it is not enough to consider just the quantity and quality of certain raw materials, it is necessary to grade the entire line of other, more or less, directly or indirectly connected components. The first element to be considered is the level of life standard of its citizens. To connect any household to any centralized heating system, certain level of life standard is required. Indirectly, the size of living space per member of household, the quality of the apartment building, the age of the building construction, its position etc. are connected with the standard. People with higher living standard, do not take into consideration only economic parameters when deciding between gas distribution and district heating system. The decision is based on personal affinity (and often, prejudice) [1].

\footnotetext{
Received June 20, 2008

* Research is financed by the Ministry of Science and Technological Development of Republic of Serbia due a scholarship program.
} 
In city conditions, the most appropriate option for satisfying heating demands is by utilization of the central system. The alternative for district heating system, with the same living standard, is the connection to gas distribution network with additional advantages by substitution of electrical energy for cooking. Today, most heating power plants are primarily disbursing natural gas. If both systems are available near the considered settlement, it is rational to connect flats on a more payable system. General methodology shown in this paper provides an optimal adoption of heating system based on scientific and economic criteria current prices and price ratios of natural gas, pipes, pumps and other elements in Serbia). Model is valid in general conditions for prices anywhere in the world, but with changes to these different inputs. These criteria are average size of buildings, average number of buildings per unit of area, natural gas price, price of system elements, e.g. prices of pipes and valves, prices of pumps or compressors, but without the expense for construction of heating power plants. The evaluation model for options of district heating or gas distribution system is developed on "Conditional Urban Area" of a hypothetical town and confirmed in a real demonstration settlement [1-5].

The present practice for heating systems selection and utilization of existing capacities in systems for centralized energy supply includes separate consideration of every single case or very often selection without clear criteria. However, characteristics of urban areas with the potential for further development of local heating by natural gas or district heating systems are different in habitant density, number of floors (stories) in buildings and their total size, type of bullding construction and insulation, distance between buildings and settlement layout. Proposed model could be useful to yrban planners, municipal officials, public utility companies, etc., as the first step in system selection. Goal of this model is to determinate characteristics of urban settlements in cities of natural gas as non-renewable fossil fuel. and to be of benefit Similar ana fit for more ro buildings (school and office building). Legal and policy aspects of different energy supply

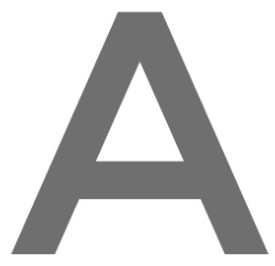
systems utilization in households sector can be found also in available literature [6-9]

\section{HypotheticAl MODEL OF SETTLEMENT}

During structure optimization of energetic supply on urban area, in the first place, it is necessary to determine the borders of observation zone. Such zone, by rule, is not homogeneous in energy demands. Very often, different density number of buildings per unit of area exists here, with different size of buildings and with different type of construction. City blocks with residential and other areas can be called for this purpose "Real Urban Area". For the model research, the term "Conditional Urban Area" can be initiated. "Real Urban Area" can be divided (parceled) into several zones with similar urban characteristics on each particular area and each part can be associated with one of the type of "Conditional Urban Areas". On the "Conditional Urban Area" it is possible to make different sorts of calculations, e.g. variation of gas or district heating pipe diameters, lengths. Changing these and other relevant parameters has an influence on the amount of construction costs and finally on the cost of energy supply. "Conditional Urban Area" can be understood as the model of real settlement that will be used as a basis for further analysis. Conclusions acquired on "Conditional Urban Area" research can be applied on "Real Urban Area". For determining the influence which density of energy 
demands and building structures (size, number and spatial disposition of building on "Real Urban Area") have on energy supply costs for the energetic model research, "Conditional Urban Area" with rectangular size with dimension approximately 160 $\mathrm{m} \cdot 315 \mathrm{~m}=0,05 \mathrm{~km}^{2}$ is adopted [2-4], [10-11]. Bigger residential area can be considered as a combination of several different "Conditional Urban Areas" with several different numbers of buildings; (see Fig. 1.). These different types adopted for model consideration are with 4, 8, 16, 32, 64 and 128 buildings per "Conditional Urban Area".
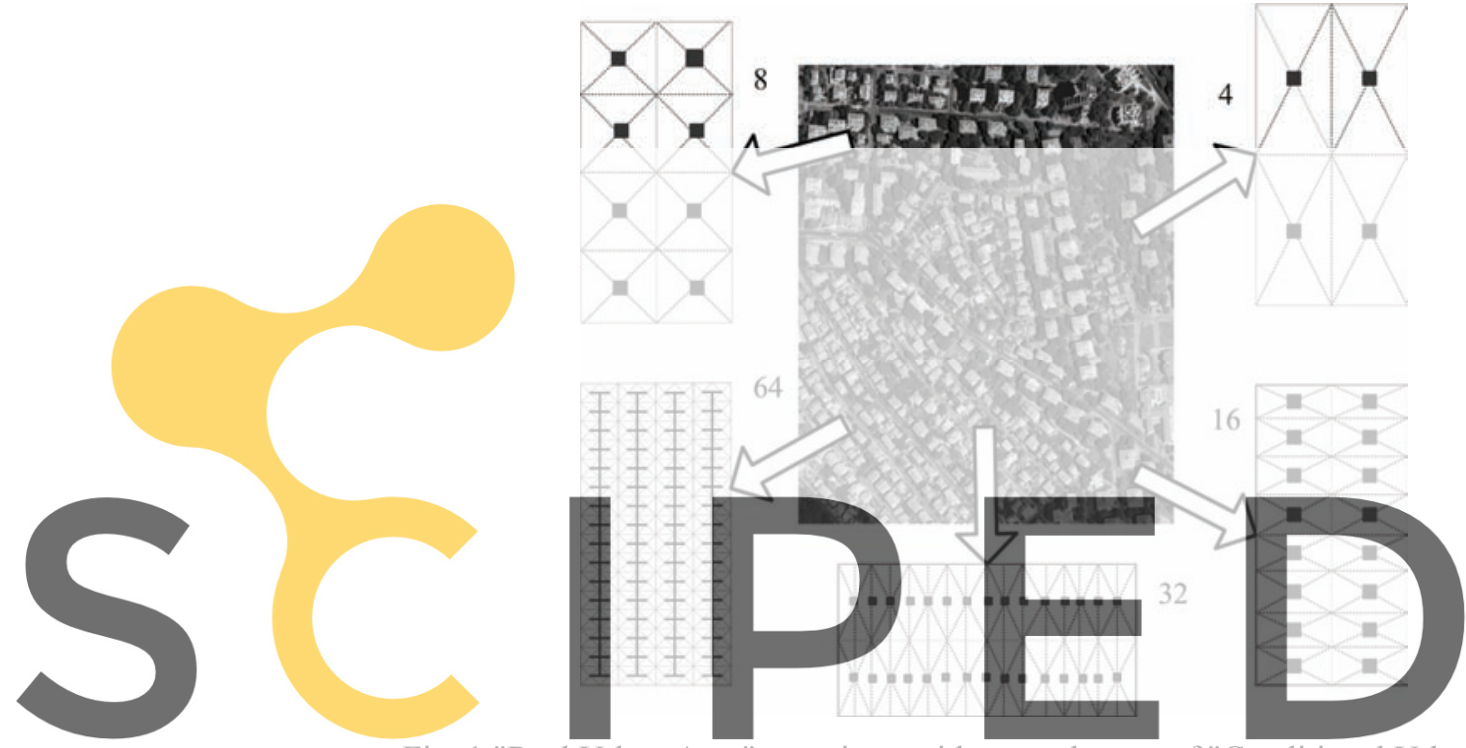

Fig. 1 "Real Urban Area" associates with several types of "Conditional Urban Areas"
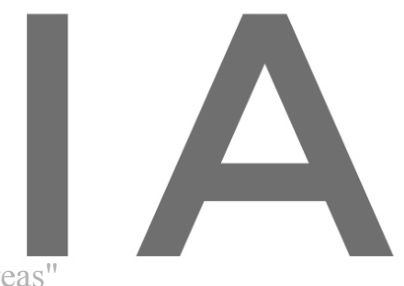

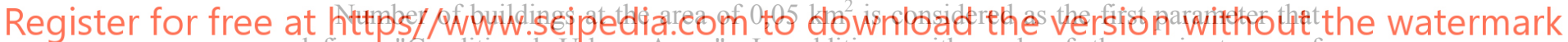
defines "Conditional Urban Areas". In addition, with each of these six types of "Conditional Urban Areas", it is possible to associate different sizes of buildings which are, in energy sense; equal to energy load, but on each particular "Conditional Urban Area" there has to be a uniform building size (see Fig. 2) [2-4], [10-11].
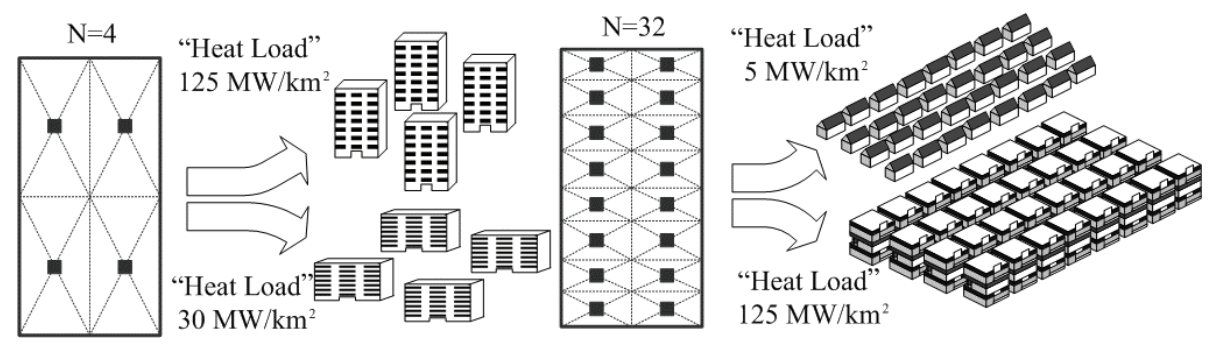

Fig. 2 "Real Urban Area" associates with several types of "Conditional Urban Areas"

Term building is used here also for family houses and similar smaller constructions in the same way of meaning as e.g. for skyscrapers. In all analyses, "Conditional Residential Unit", i.e. "Conditional Flat" with net heating area of $60 \mathrm{~m}^{2}$ is observed. 
Similarity between "Conditional Urban Area" and "Real Urban Area" can be determined by two different independent quantities:

1) Heat demand of urban area ("Heat Load" or peak load densities of all heated buildings on a zone divided by size of an area), $\mathrm{MW} \cdot \mathrm{km}^{-2}$; (see Fig. 2)

2) Number of buildings on urban area (number of buildings on $0,05 \mathrm{~km}^{2}-5$ hectares); (see Fig. 1)

Different peak load densities or "Heat Load" i.e. size of buildings can correspond to the same number of buildings at structural urban area; Fig. 2. Peak load densities (can be marked as X) of $10 \mathrm{MW} \cdot \mathrm{km}^{-2}, 20 \mathrm{MW} \cdot \mathrm{km}^{-2}, 30 \mathrm{MW} \cdot \mathrm{km}^{-2}, 40 \mathrm{MW} \cdot \mathrm{km}^{-2}, 50 \mathrm{MW} \cdot \mathrm{km}^{-2}, 75$ $\mathrm{MW} \cdot \mathrm{km}^{-2}, 100 \mathrm{MW} \cdot \mathrm{km}^{-2}$ or $125 \mathrm{MW} \cdot \mathrm{km}^{-2}$ are chosen for analysis to include wide range of possible real urban situations. "Conditional Flat" has, for the purpose of model approach, heat demand of $142 \mathrm{~W} \cdot \mathrm{m}^{-2}$ (heat peak load for lower insulated flat) in case of lower (bad) insulation, and in case of better (good) insulation heat demand of $95 \mathrm{~W} \cdot \mathrm{m}^{-2}$ (heat peak load for better insulated flat). Each combination of defined number of buildings and peak load density corresponds to different number of average dwellings in the building (from minimal number; $y=0,509$ "Conditional Flat" per building to maximum number; $y=180,45$ "Conditional Flats" per building) [12-14]. These numbers can be set according to following equations (1-6):
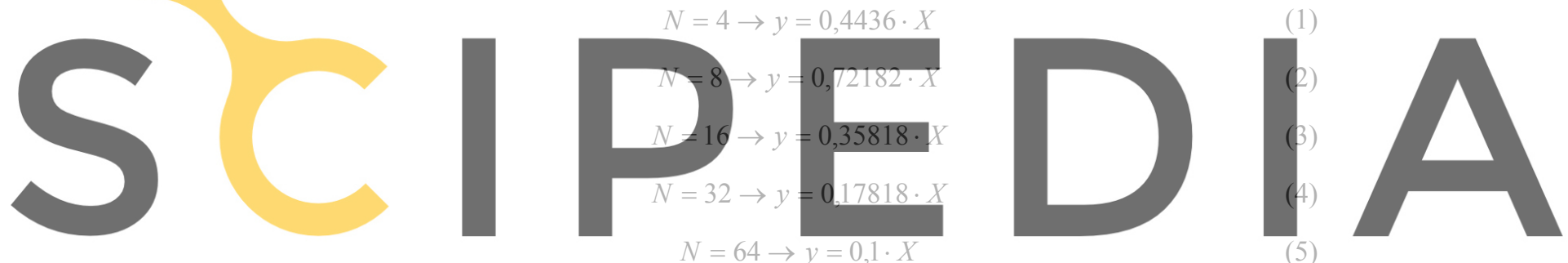

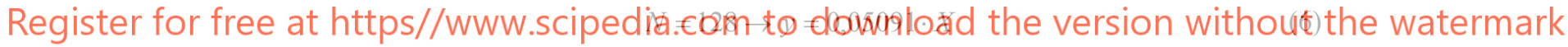

\section{TECHNO-ECONOMICAL MODEL OF RATIONAL NATURAL GAS USAGE}

While determining the investment costs, it is necessary to include all possible expenses within borders of the system. Infrastructure, common for both systems (gas distribution and district heating) is not calculated because these costs can abbreviate during comparisons (see Fig. 3). In figure 3, exploitation and transport (including storage) is common for both systems, while distribution of gas or district heating have different costs. Internal heating infrastructure (radiators) in a flat is common for both systems. While developing a model, investments in gas distribution network and investments in district heating pipeline are done separately. Each separate system has different elements, e.g. district heating system is built with iron pipes, pumps and heat exchangers, on the contrary, gas distribution system is built with cheaper polyethylene pipes and has stations for measuring and regulation with internal gas equipment (each flat has domestic gas boiler etc. Investment in a new heat power plant is not calculated for a model, available capacities in existing power plants have to be regarded [15-18]. 
Relative (per "Conditional Flat") investments (included annual costs as below) in district heating $-\mathrm{DH}$ and in local gas heating system $-\mathrm{G}$ (each and everyone "Conditional Flat" is equipped with domestic boiler fueled by natural gas) can be calculated after following equations (7-8) [2-5], [19-23]

$$
\mathrm{DH}=\frac{\mathrm{DHN}+\mathrm{HE}+\mathrm{DHOC}}{\mathrm{y}}
$$

where:

DHN $[€]$ - costs of District Heating Network, i.e. costs of building/civil works, costs of materials (insulated pipes, pumps, accessories, etc.) and telemetry systems, etc

$\mathrm{HE}[€]$ - costs of Heat Exchanger stations located in buildings,

DHOC $[€]$ - annual costs of maintenance calculated as percentage of investment, in network (2,5\%); lifetime 25 years, heat exchanger station (1,5\%); lifetime 12 years, annual natural gas consumption-10\% more than in system with domestic boiler in each "Conditional Flat" $\left(942,7 \mathrm{~m}^{3}\right.$ per "Conditional Flat" - $\left.0.12 € \cdot \mathrm{m}^{-3}\right)$ and annual electricity consumption for pumps drive $\left(250 \mathrm{kWh}-0,035 € \cdot \mathrm{kWh}^{-2}\right)$

y - number of "Conditional Flats" per "Conditional Urban Area"

$$
\mathrm{G}=\underline{\mathrm{MPRS}+\mathrm{PRS}+\mathrm{DN}+\mathrm{DS}+\mathrm{B}+\mathrm{GOC}}
$$
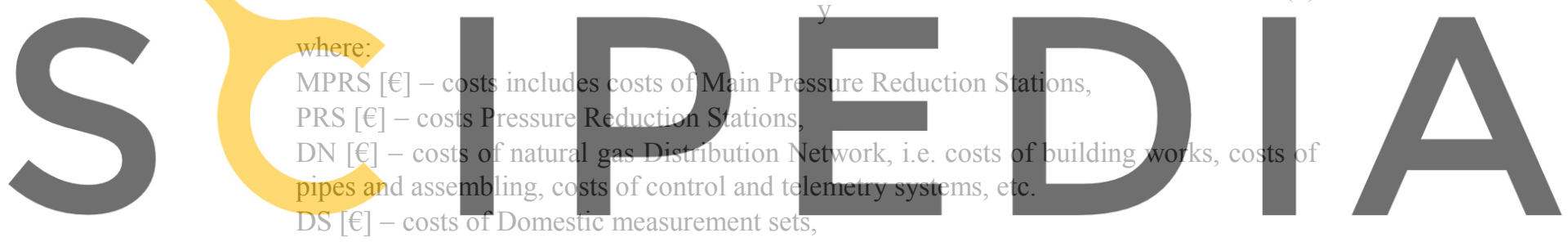

$\mathrm{B}[€]$ - costs of domestic boilers

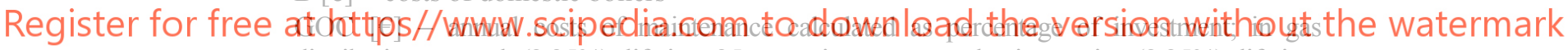
distribution network (2,25\%); lifetime 25 years, in pressure reduction station (2,25\%); lifetime 25 years, in measurement set (2,25\%), lifetime 12 years, domestic boiler (2,25\%), lifetime 12 years and annual natural gas consumption $\left(857 \mathrm{~m}^{3}\right.$ per "Conditional Flat" - $\left.0.12 € \cdot \mathrm{m}^{-3}\right)$

Costs joined to each "Conditional Flat" are costs of Domestic measurement sets DS $[€]$, and costs of domestic boilers B [€]

In the equations above are not shown costs common for both systems. Different investments in these two opposite systems can be compared for the purpose of a model

All previous investments are considered for present conditions in Serbian energy sector. This means that heat sources (district heating plants) and primary natural gas infrastructure (gas transmission pipelines and high/medium-pressure gas stations) have already existed in the greatest number of Serbian towns and have allowed connection of new consumers without further investments. Of course, this model is applicable for conditions and particular cases all over the world, but diagrams (figures in this paper) are generated for prices relation in Serbia. 


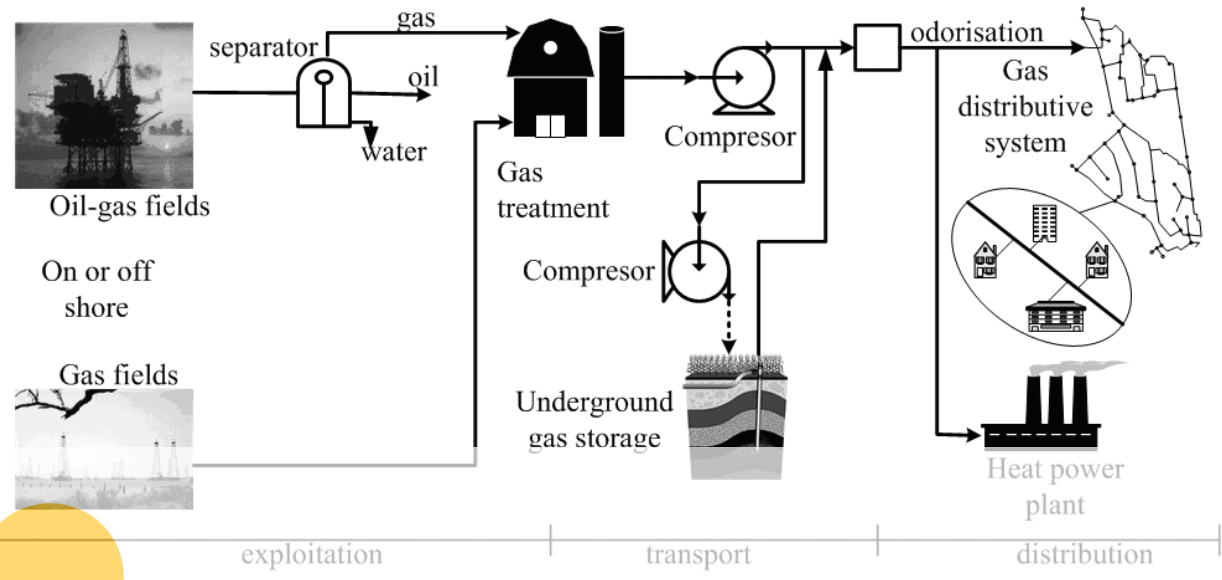

Fig. 3 Flows of natural gas from fields to consumers

District heating and natural gas networks are designed for 48 different combinations, according to previously defined peak load densities and numbers of buildings. Generally,

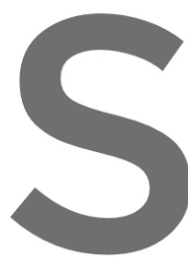

each project

shown here has

elements has rea

a project, during

replacement

some after 25

here is labeled as
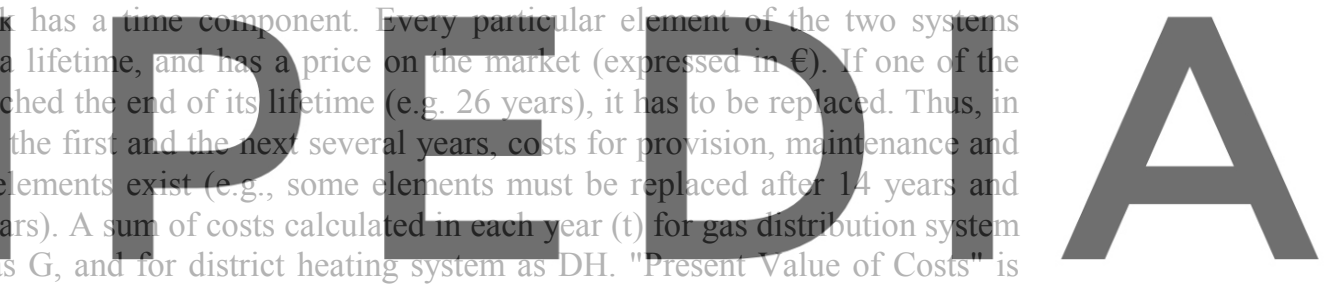

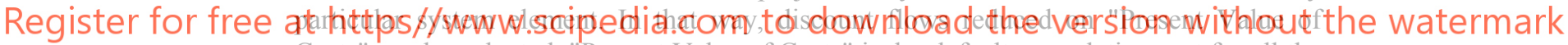

Costs" can be valuated. "Present Value of Costs" is, by default, cumulative cost for all the

elements of the system in present and in future expanded for discount rate. "Future Value

of Costs" has to be reduced to present value and to be added to real present costs. Thus, generated value is called "Present Value of Costs". For the reduction of "Future Value of Costs", appropriate "Discount Rate" (Dr) has to be adopted. Higher value of "Discount Rate" is calculated when risks for the safety of investments exist. "Discount Rate" could be equalized with "Interest" on the market or for realized credit [2, 24].

In our case, economical evaluation is realized during comparison of two "Present Values of Costs", for gas distribution system $(\mathrm{G})$ and for district heating system (DH). "Net Present Value of Costs" (NPV) (9) is the result of subtraction of "Present Value of Costs" calculated for district heating system (DH) and "Present Value of Costs" calculated for gas distribution system $(\mathrm{G})$.

$$
\mathrm{NPV}=\sum_{\mathrm{t}=1}^{\mathrm{n}} \frac{\mathrm{DH}-\mathrm{G}}{\left(1+\mathrm{D}_{\mathrm{r}}\right)^{\mathrm{t}}}
$$

These costs are calculated for all six types; Fig. 1 of "Conditional Urban Area". With every particular type of "Conditional Urban Area" eight different "Heat Loads"; (see Fig. 
2) can be associated. All costs are reduced to a flat with net heating size of $60 \mathrm{~m}^{2}$ ("Conditional Flat"). Value of "Discount Rate" in this case is rated and adopted as $\mathrm{Dr}=10 \%$. Annual gas consumption calculated for one "Conditional Flat" is $857 \mathrm{~m}^{3}$ for heating only, and for district heating system, this amount is for $10 \%$ higher. Annual costs of electrical energy for running of pumps for district heating system are estimated to 250 kWh per "Conditional Flat". Analyses are done for all 48 cases (six "Conditional Urban Area" multiplied by eight "Heat Loads") for the period of $\mathrm{t}=26$ years (Table 2). Value of "Discount Rate" in this case is rated and adopted as $\mathrm{Dr}=10 \%$.

Table 1 Costs for gas distribution system and district heating system (example $\mathrm{N}=32$, "Heat Load" $=75 \mathrm{MW} \cdot \mathrm{km}^{-2}$ - one of 48 cases, 14 "Conditional Flat" per building)

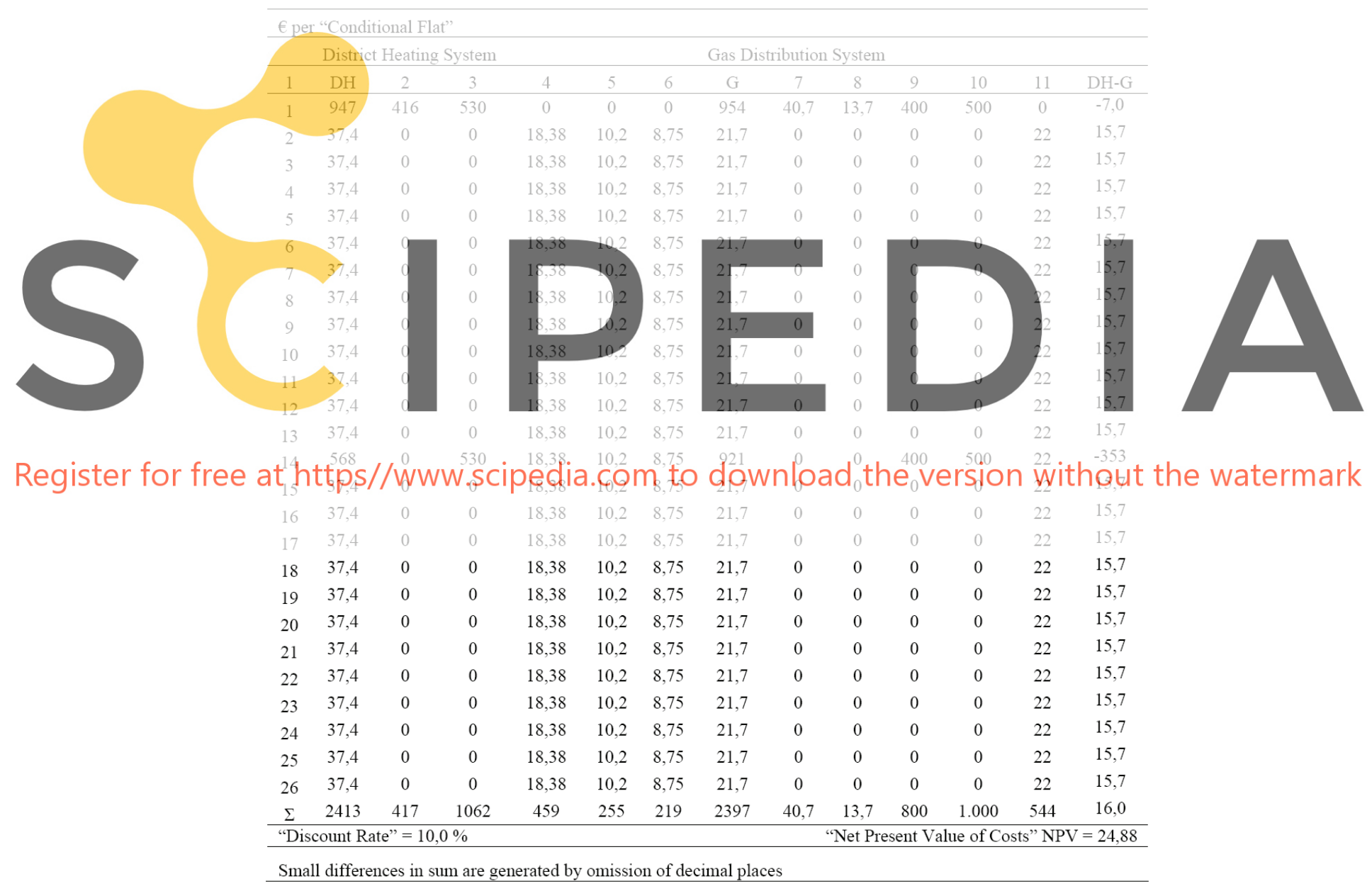

where (in Table 1, third line from top): 1. Year of project, 2. District heating pipeline, 3. Heat exchanger, 4. Maintenance of gas distribution system, 5. Cost for additional gas, 6. Cost for electrical energy, 7. Gas Distribution pipeline, 8. Cost for regulation station, 9. Cost for household connection set, 10. Cost for Gas Boiler, 11. Maintenance of district heating system 
Table 2 "Net Present Value of Costs" (NPV) - € per "Conditional Flat"

\begin{tabular}{|l|c|c|c|c|c|c|c|c|}
\hline \multicolumn{1}{|l|}{ Number of buildings } \\
\hline & \multicolumn{1}{|c|}{ "Heat Loads", MW·km } & -2 \\
\cline { 2 - 8 } & $\mathbf{1 2 5}$ & $\mathbf{1 0 0}$ & $\mathbf{7 5}$ & $\mathbf{5 0}$ & $\mathbf{4 0}$ & $\mathbf{3 0}$ & $\mathbf{2 0}$ & $\mathbf{1 0}$ \\
\hline $\mathbf{N = 4}$ & -802 & -749 & -689 & -532 & -451 & -283 & -9 & 467 \\
$\mathbf{N}=\mathbf{8}$ & -671 & -599 & -492 & -291 & -166 & 42 & 223 & 985 \\
$\mathbf{N}=\mathbf{1 6}$ & -454 & -364 & -203 & -5 & 157 & 398 & 695 & 1.959 \\
$\mathbf{N}=\mathbf{3 2}$ & -152 & -80 & 25 & 377 & 635 & 1.015 & 1.652 & 3.587 \\
$\mathbf{N}=\mathbf{6 4}$ & 65 & 163 & 363 & 730 & 1.348 & 1.415 & 2.623 & 5.791 \\
$\mathbf{N}=\mathbf{1 2 8}$ & 467 & 530 & 1.048 & 1.504 & 2.135 & 3.171 & 4.820 & 6.614 \\
\hline
\end{tabular}

Negative values: district heating system has advantage

Positive values: gas distribution system has advantage

Calculations from table 2 are graphically shown in figure 4 and 5. Each individual case, in practice, should be considered in detail using the methodology mentioned in this study.
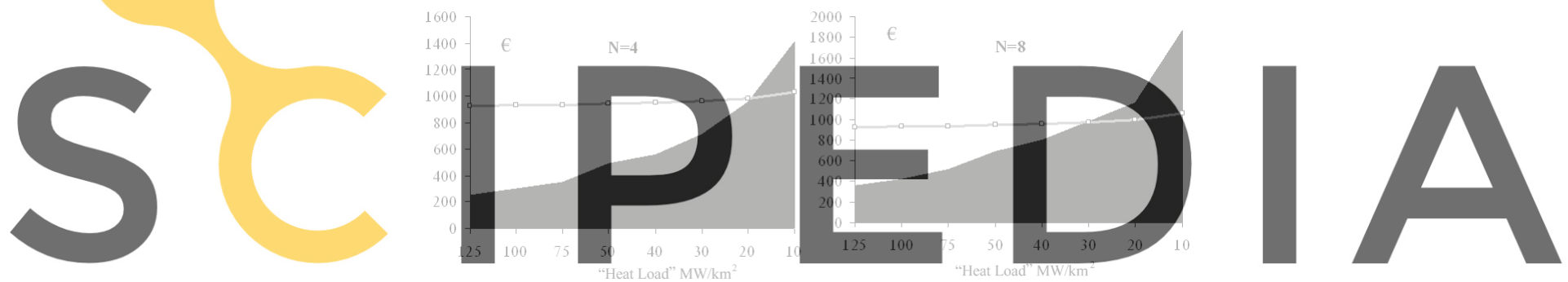

Register for free at https//wwW.scipendia.com to downiload the version without the watermark
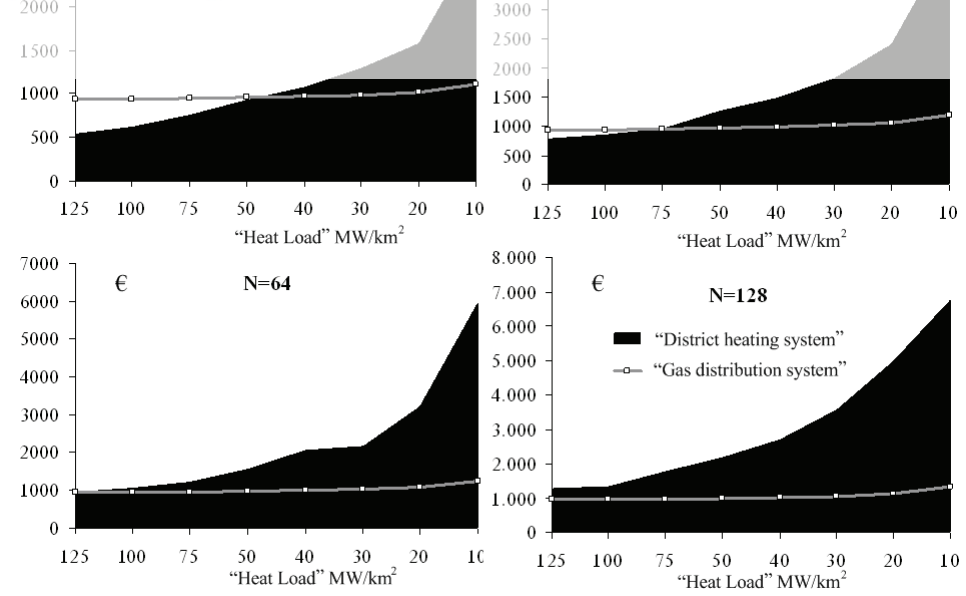

Fig. 4 "Present Value of Costs" (NPV) - $€$ per "Conditional Flat" for district heating system and gas distribution system. 
The values in certain cases in table 2 vary more or less from zero. For example, for "Conditional Urban Area" with 16 buildings and with "Heat Loads" $50 \mathrm{MW} \cdot \mathrm{km}^{-2}$, calculated "Net Present Value of Costs" (NPV) is only -5 per "Conditional Flat" for a period of 26 years. Therefore, in this case, realization of gas distribution system for that "Conditional Flat" is only $5 €$ for 26 years in advantage versus district heating system. This case and other similar are in the "gray zone"; (see Fig. 5). In the "gray zone", both systems are payable, especially for a period of 26 years.

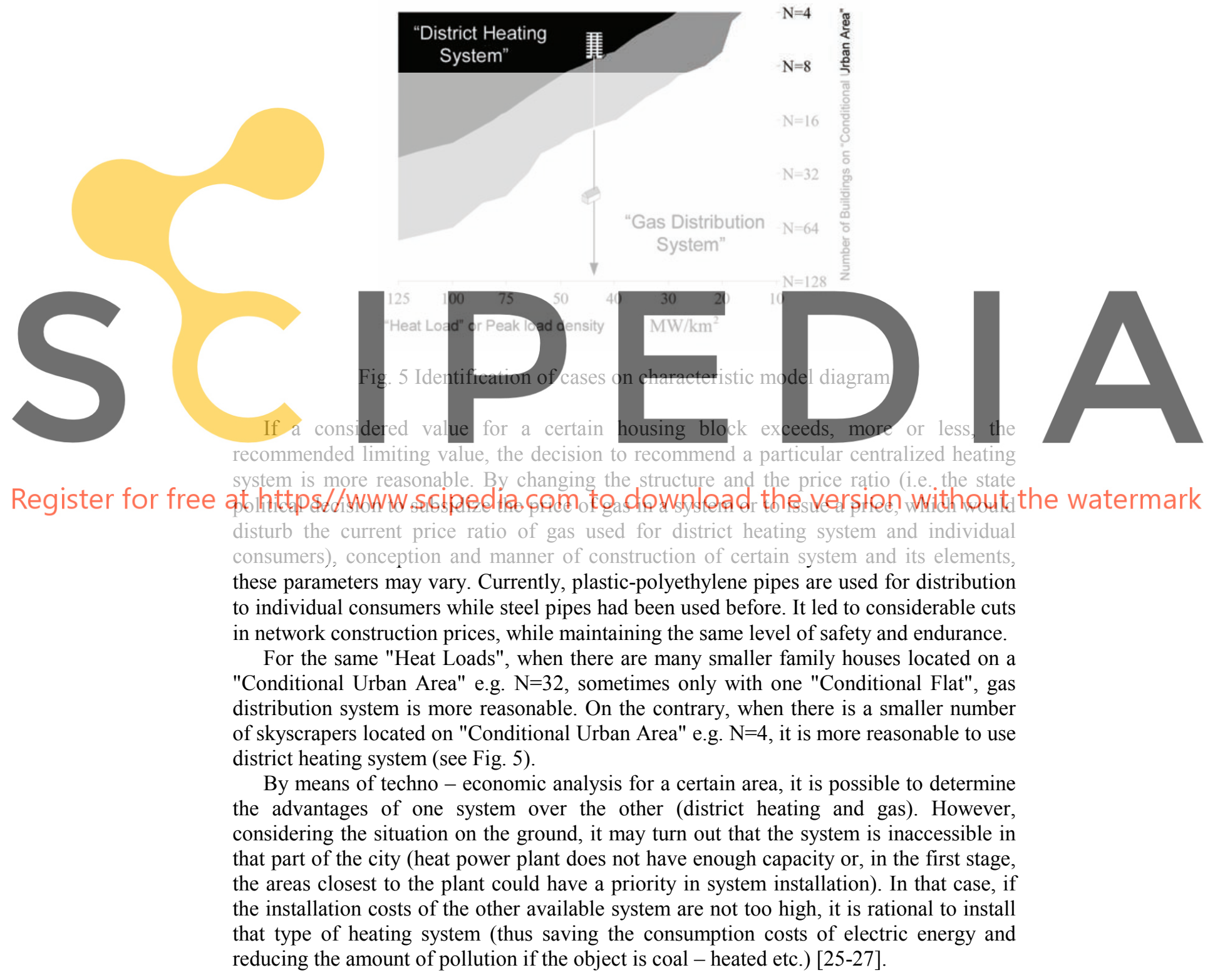


The biggest disadvantage of choosing the district heating system is that the payment is based on the volume of heated area that is in conflict with energy conservation. On the other hand, compared to gas, this system is safer since the combustion is not conducted inside a flat, which reduces the dangers of explosion and suffocation.

The additional advantage of the gas system is its substitution with the electric energy used for cooking.

If, after the analysis, it turns out that one system has more significant economic advantages than the others do, but it is unavailable, some form of hybrid system should be considered. For instance, if the installation of district heating system has a lot of economic advantages but it is not available, it is possible to build a local boiler room which would be gas operated. This hybrid solution would demand additional economic and ecologic analyses and estimations of which good features of district heating system would be kept and which would be discarded.

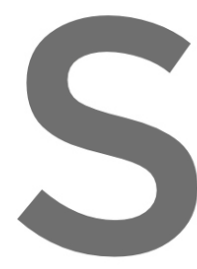

\section{APPLYING OF THE MODEL IN REAL CONDITIONS}

Characteristics of "Real Urban Area": number of buildings, disposition and size of buildings, construction type, etc. are the factors of influence [2-3], [28-34].

\section{Register for free at https//www.scipedia.com to of ônnload the version without the watermark}

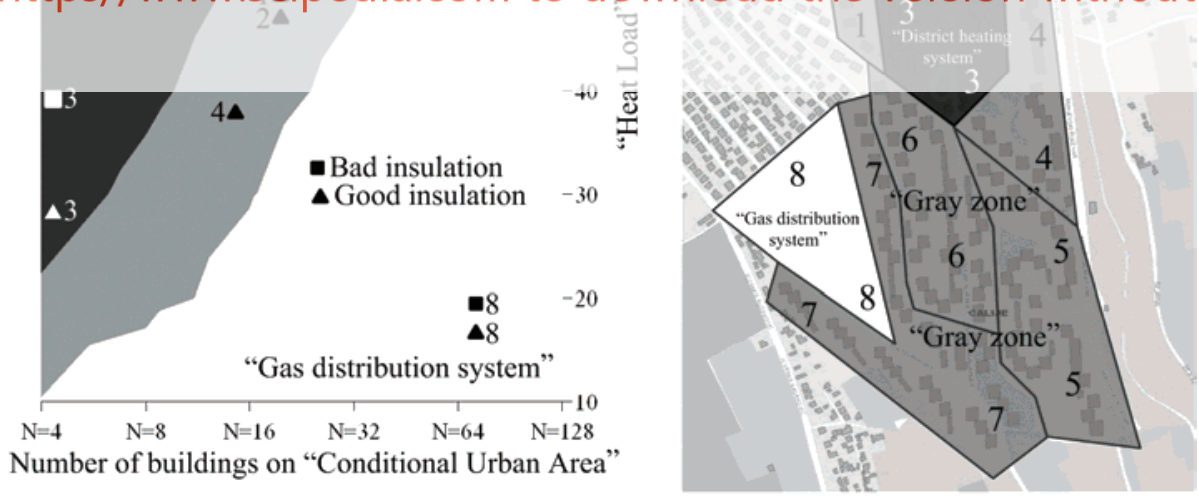

Fig. 6 Diagram for adoption of optimal system

Length and structure of pipeline, heat load, fuel consumption, apropos investments' and maintenance costs and exploitation of centralized systems depend on these specified factors of influence. Adoption of type of centralized heating system can be done 
according to the conclusion established by the model shown. That is possible only if both systems are available near the settlement. In that case, type of the chosen system depends only on urban characteristic of the settlement. Because of that, the demonstrative settlements are parceled (divided) into eight "Real Urban Areas" with similar buildings on each particular parcel (see Fig. 6). That way, the determined "Real Urban Area" can be associated with "Conditional Urban Area". Characteristic points for each of the eight parcels (intersection of number of buildings and heat load of parcel) can be plotted into the characteristic model diagram; (see Fig. 6). The characteristic model diagram can be like on figure 6 or counterclockwise like on figure 5 because both axes have the same priority. The types of insulation of the buildings in the settlement are mixed; old buildings have bad and new buildings have good insulation. Both old and new buildings have heterogeneous disposal.
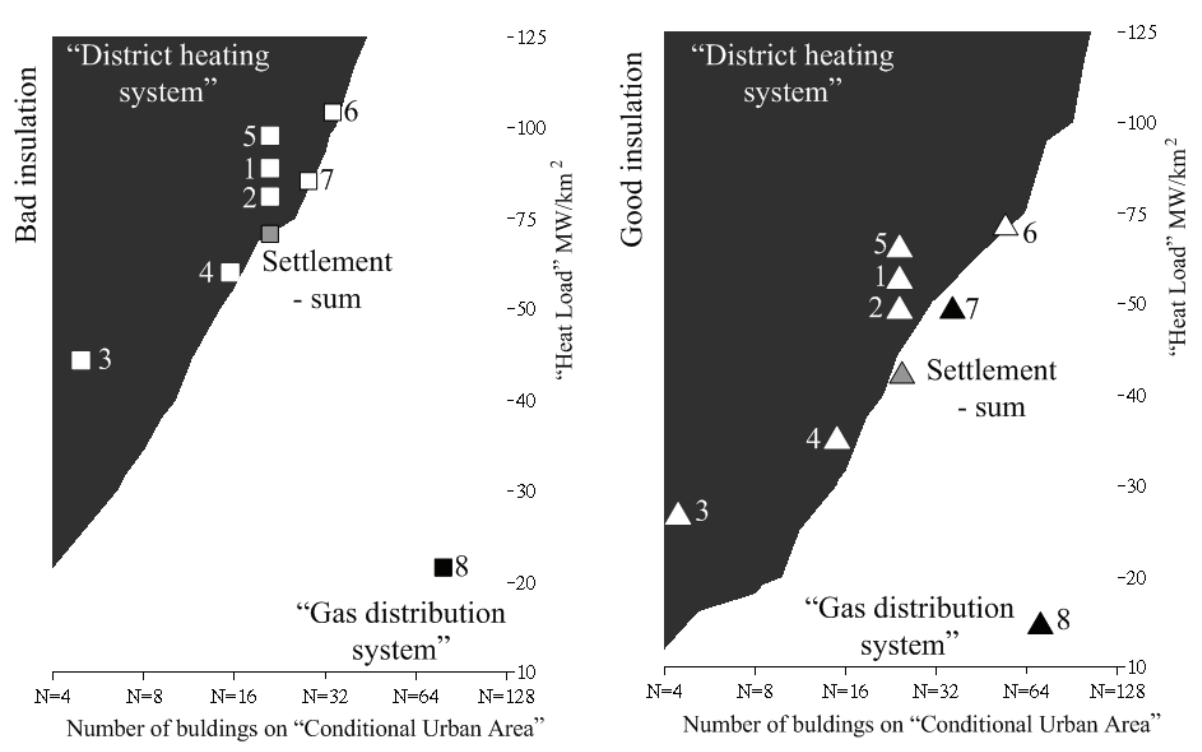

Fig. 7 Displacement of borders and characteristic points calculated for different quality of building insulation

Two border cases have been treated, because of heterogeneity of insulation quality of buildings; (see Fig. 7):

- Maximal "Heat Load", all buildings have bad insulation $\left(144 \mathrm{~W} \cdot \mathrm{m}^{-2}\right)$,

- Minimal "Heat Load", all buildings have good insulation $\left(95 \mathrm{~W} \cdot \mathrm{m}^{-2}\right)$,

The value of fuel consumption depends on heating insulation of the building. Therefore, "Heat Load" depends on heating insulation of the building. The number of buildings on each particular parcel is constant. "Gray zone" is the zone where decision on the type of the system depends very much on the type of insulation of the building; (see Fig. 6). In the "Gray zone", the costs for both systems (gas distribution system and district heating system) are very similar. Characteristic points for each of eight particular also depend on the quality of insulation. 
"Real Urban Area" No 8 includes types of small buildings or family houses which can contain only one "Conditional Flat". Only for that, "Real Urban Area" the gas distribution system has very payable advantages versus district heating system. "Real Urban Area" No 3 includes school, kindergarten, local office, shops. These kinds of buildings can contain twenty or more "Conditional Flats". Only for that, "Real Urban Area" the district heating system has great advantages. All other zones are in "gray zone". In a "gray zone", one system is more payable in comparison with the other, no more than $200 €$ per "Conditional Flats". This amount cannot be crucial for decision.

Using one power resource (in this case natural gas) in various systems, the difference for amount of pollution is very little. Big differences cannot occur in the overall effect on the city level, but in certain areas. While heating plant is a concentrated pollutant which disperses harmful combustion products evenly on a wide area depending on the wind, gas lined consumption disperses locally (consumer pollutes his nearest neighborhood). Globally, the biggest gas consumer is the biggest city polluter. Considering the city ecology, it is possible to analyze the use of unconventional gas that solves the deposit problem etc. This problem is far more complicated and exceeds the volume of this study that primarily deals with the use of natural gas. For including environmental impacts of different centralized energy supply systems in model, it is necessary to estimate annual environmental costs for both systems and to include them in related equations.

Comparing all of the fossil fuels, natural gas is a minor pollutant. It burns without a solid residue and has the least coefficient of $\mathrm{CO}_{2}$ emission of about $56 \mathrm{~kg} \cdot \mathrm{GJ}^{-1}$ (which is significant considering the limitations imposed by The Kyoto Protocol).

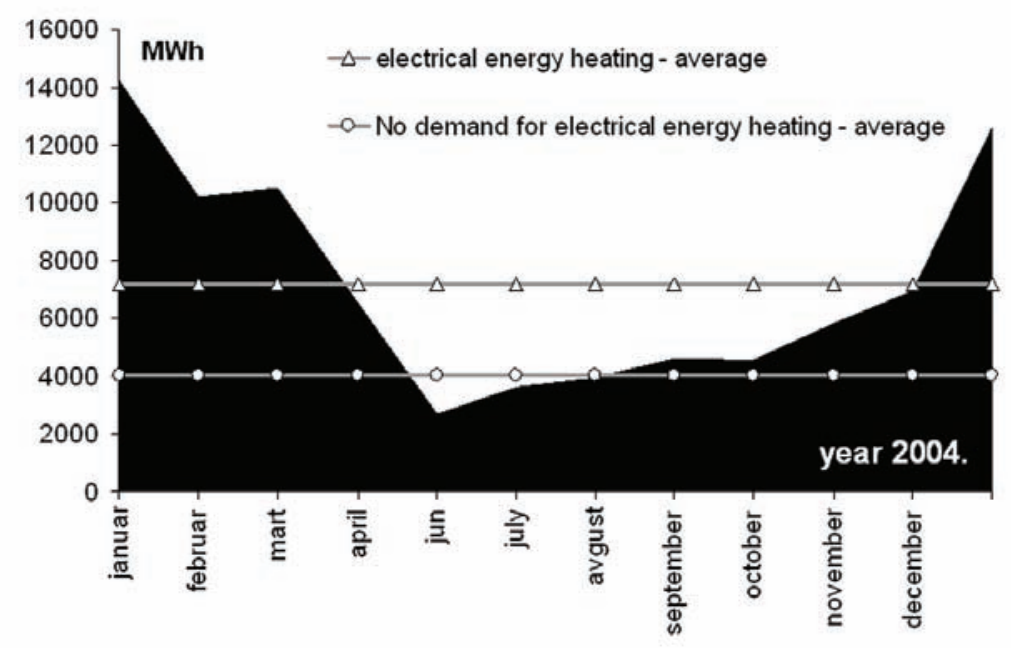

Fig. 8 Consumption of electrical energy in the observed settlement

The key advantage of installing gas or district heating system is not in their mutual differences, but in substitution of the far more expensive (in terms of energy and ecology) and the highest quality form of energy - the electric energy, whose usage for heating is by far less rational (see Fig. 8). 


\section{CONCLUSION}

The conducted analyses confirm literature and empirical information.

- With higher number of heating consumers and a small object density, i.e. large number of apartments per object, district heating system is a better solution.

- Gas system is a better option in areas with high object density and, relatively, small number of consumers.

In more detail, if a certain number of objects $\mathrm{N}$ exist in a "Conditional Urban Area", it can be concluded that:

$\mathrm{N}=4$, district heating system has an advantage over gas if an average building has over 29 conditional apartments (i.e. if the overall heating surface is over $1740 \mathrm{~m}^{2}$ )

$\mathrm{N}=8$, district heating system has an advantage over gas if an average building has over 22 conditional apartments (i.e. if the overall heating surface is over $1320 \mathrm{~m}^{2}$ )

$\mathrm{N}=16$, district heating system has an advantage over gas if an average building has over 18 conditional apartments (i.e. if the overall heating surface is over $1080 \mathrm{~m}^{2}$ )

$\mathrm{N}=32$, district heating system has an advantage over gas if an average building has over 15 conditional apartments (i.e. if the overall heating surface is over $900 \mathrm{~m}^{2}$ )

$\mathrm{N}=64$, district heating system has an advantage over gas if an average building has over 12 conditional apartments (i.e. if the overall heating surface is over $702 \mathrm{~m}^{2}$ )

$\mathrm{N}=128$, gas system is practically always advantageous.

Based on the heat load, limiting parameters can be summed in regards to the number of objects per conditional construction area for:

$\mathrm{N}=4$, district heating system has an advantage over gas if the heat load exceeds 20 $\mathrm{MW} \cdot \mathrm{km}^{-2}\left(1.000 \mathrm{~kW}\right.$ per $0,05 \mathrm{~km}^{2}$ i.e. 5 ha $)$

$\mathrm{N}=8$, district heating system has an advantage over gas if the heat load exceeds 30 $\mathrm{MW} \cdot \mathrm{km}^{-2}\left(1.500 \mathrm{~kW}\right.$ per $0,05 \mathrm{~km}^{2}$ i.e. 5 ha $)$

$\mathrm{N}=16$, district heating system has an advantage over gas if the heat load exceeds 50 $\mathrm{MW} \cdot \mathrm{km}^{-2}\left(2.500 \mathrm{~kW}\right.$ per $0,05 \mathrm{~km}^{2}$ i.e. $\left.5 \mathrm{ha}\right)$

$\mathrm{N}=32$, district heating system has an advantage over gas if the heat load exceeds 75 $\mathrm{MW} \cdot \mathrm{km}^{-2}\left(3.750 \mathrm{~kW}\right.$ per $0,05 \mathrm{~km}^{2}$ i.e. 5 ha $)$

$\mathrm{N}=64$, district heating system has an advantage over gas if the heat load exceeds 150 MW $\mathrm{km}^{-2}\left(7.500 \mathrm{~kW}\right.$ per $0,05 \mathrm{~km}^{2}$ i.e. $\left.5 \mathrm{ha}\right)$

$\mathrm{N}=128$, gas system is practically always advantageous.

If large areas are covered by agricultural terrain, by excluding it, the above-mentioned parameters obtain unrealistic values. In this case, it is better to consider the length of routes. For:

$\mathrm{N}=4$, district heating system is an advantage if the length of route is about $8 \mathrm{~m}$

$\mathrm{N}=8$, district heating system is an advantage if the length of route is about $7,6 \mathrm{~m}$

$\mathrm{N}=16$, district heating system is an advantage if the length of route is about $7 \mathrm{~m}$

$\mathrm{N}=32$, district heating system is an advantage if the length of route is about $6,4 \mathrm{~m}$

$\mathrm{N}=64$, district heating system is an advantage if the length of route is about $5,8 \mathrm{~m}$

The above-mentioned limiting values for use of gas are consistent in case of an average heat-isolated apartment of $60 \mathrm{~m}^{2}$. In other cases, additional corrections should be made, or different input values must be entered in the model.

Acknowledgement: The paper is a part of the research done within the project of Ministry of Science NP EE 34-406A, Serbia, Belgrade. The author would like to thank to the Ministry of Science for financial support. 


\section{REFERENCES}

1. Santamouris M., Kapsis K., Korres D., Livada I., Pavlou C., Assimakopoulos M.N.: On the Relation Between the Energy and Social Characteristics of the Residential Sector, Energy and Buildings, 39, Elsevier, 2007, pp. 893-905.

2. Бркић Д.: Природни гас као гориво за грејање; Academia, Vol. 169, Задужбина Андрејевић, Београд, 2006, стр. 1-94.

3. Бркић Д.: Одређивање границних параметара употребе природног гаса у Београду, магистарска теза, Рударско-геолошки факултет, Београд, 2005, стр. 1-205

4. Бркић, Д.: Варијанте индиректне и директне употребе природног гаса за грејање станова, Техничка дијагностика, 3, Београд, 2007, стр. 41-48

5. Gustavsson L., Karlsson A.: Heating Detached Houses in Urban Areas, Energy, 28, Elsevier Pergamon, 2003, pp. 851-875

6. Myoung-Souk Y., In-Ho Y., Kwang-Woo K.: Historical Changes and Recent Energy Saving Potential of Residential Heating In Korea, Energy and Buildings, 35, Elsevier, 2003, pp. 715-727

7. Torekov M. S., Bahnsen N., Qvale B.:The Relative Competitive Positions of the Alternative Means for Domestic Heating, Energy, 32, Elsevier Pergamon, 2007, pp. 627-633

8. Lazzarin R., Noro M.: Local or District Heating by Natural Gas: Which is Better from Energetic, Environmental and Economic Point of Views?, Applied Thermal Engineering, 26, Elsevier, 2006, pp. 244-250

9. Grohnheit P. E., Mortensen B. O. G.: Competition in the Market for Space Heating. District Heating as the Infrastructure for Competition Among Fuels and Technologies, Energy Policy, 31, Elsevier, 2003, pp. $817-826$

10. Танасковић Т., Ђајић Н., Танасијевић М., Бркић Д.: Анализа карактеристика гасификације и топлификације на моделу условне грађевинске површине, конференција XXXI SYM-OP-IS, Иришки Венац, 2004, стр. 69-72

11. Живковић М., Бркић Д.: Избор централизованог система снабдевања енергијом демо насеља, конференција XXXII SYM-OP-IS, Врњачка Бања, 2005, стр. 175-178

12. Jaber J. O.: Prospects of Energy Savings in Residential Space Heating, Energy and Buildings, 34, Elsevier, 2002, pp. 311-319

13. Papadopoulos A.M., Oxizidis S., Papandritsas G.: Energy, Economic and Environmental Performance of Heating Systems in Greek Buildings, Energy and Buildings, 40, Elsevier, 2008, pp. 224-230

14. Бркић Д.: Цене природног гаса у Србији и у свету, конференција МАРЕН, Београд, 2006, стр. 419425

15. Бркић Д., Танасковић Т.: Утицајни фактори на формирање цене природног гаса, конференција XXXIII SYM-OP-IS, Бања Ковиљача, 2006, стр. 181-184

16. Mihalakakou G., Santamouris M., Tsagrassoulis A., On the Energy Consumption in Residential Buildings, Energy and Buildings, 34, Elsevier, 2002, pp. 727-736.

17. Olesen B.W., Parsons K.C.: Introduction to Thermal Comfort Standards and to the Proposed New Version of EN ISO 7730, Energy and Buildings, 34, Elsevier, 2002, pp. 537-548.

18. Huei-Chu L., Tsai-Feng C.: Space-Heating and Water-Heating Energy Demands of the Aged in the US, Energy Economics, Elsevier North-Holland, 24,2002, pp. 267-284

19. Бркић Д., Танасковић Т.: Поређење гасних котлова у домаћинствима на основу сезонске ефикасности, конференција XXXIV SYM-OP-IS, Златибор, 2007, стр. 167-170

20. Танасковић Т., Бркић Д.: SEDBUK - Британска методологија за одређивање сезонске ефикасности гасних котлова, ГАС, ХII/1, Београд, 2007, стр. 17-22

21. Танасковић Т., Бркић Д.: Сезонска ефикасност кућних гасних котлова, конференција XXXIV SYM-OP-IS, Златибор, 2007, стр. 171-174

22. Corfield G., Hunt B. E., Ott R. J., Binder G. P., Vandaveer F. E.: Gas Engineers Handbook, (ed. C. George Segeler et al.), 1st edn, Industrial Press, New York, 1974, pp. 9/63-9/83

23. Recknagel H., Sprenger E., Honmann W.: Грејање и климатизација - приручник, (ed. Z. Ceperković et al.), 2nd edn,; Građevinska knjiga, Beograd, 1984, str. 293-835

24. Papadopoulos A.M., Theodosiou T., Karatzas K.: Feasibility of Energy Saving Renovation Measures in Urban Buildings: the Impact of Energy Prices and the Acceptable Pay Back Time Criterion, Energy and Buildings, 34, Elsevier, 2002, pp. 455-466.

25. Braniš M., Domasova M., Rezačova P.: Particulate Air Pollution in a Small Settlement: The effect of local heating, Applied Geochemistry, 22, Elsevier Pergamon, 2007, pp. 1255-1264 
26. Бркић Д., Танасковић Т.: Природни гас као еколошки најприхватљивије фосилно гориво, конференција МАРЕН, Београд, 2006, стр. 225-230

27. Бркић Д.: Утицај природног гаса на ефекат стаклене баште, конференција ЕЖЕТ ХХІ, Београд 2006, CD

28. Gonzalez A.D., Carlsson-Kanyama A., Crivelli E.S., Gortari S.: Residential Energy Use in One-Family Households with Natural Gas Provision in a City of the Patagonian Andean Region, Energy Policy, 35, Elsevier, 2007, pp. 2141-2150

29. Sadegh Zadeh S.M.: An Energy Efficiency Plan for the Iranian Building Sub-Sector, Energy Policy, 35 , Elsevier, 2007, pp. 1164-1171

30. Lunda H., Hvelplunda F., Kassb I., Dukalskisb E., Blumberga D.: District Heating and Market Economy in Latvia, Energy, 24, Elsevier Permagon, 1999, pp. 549-559

31. Бркић, Д.: Провера модела условних површина грејања на гас у насељима, Техничка дијагностика, 4, Београд, 2007, стр. 39-44

32. Haberl H., Adensam H., Geissler S.: Optimal Climate Protection Strategies for Space Heating; The Case of Austria, Energy Policy, 26 (15), Elsevier, 1998, pp. 1125-1135

33. Cowie A.L., Kirschbaumb M.U.F., Ward M.: Options for Including All Lands in a Future Greenhouse Gas Accounting Framework, Environmental Science \& Policy, 10, Elsevier, 2007, pp. 306-321

34. Karlssona A., Gustavsson L.: External Costs and Taxes in Heat Supply Systems, Energy Policy, 31, Elsevier, 2003, pp. 1541-1560

\section{GREJANJE NA PRIRODNI GAS U NASELJIMA SRBIJE U SKLADU SA URBANISTIČKIM PARAMETRIMA \\ Dejan Brkić}

Prirodni gas može biti korišćen direktno za grejanje preko gasne distributivne mreže. Posredno, prirodni gas može da se koristi kao gorivo za toplanu i da se putem daljinskog sistema grejanja isporučuje toplotna energija za grejanje stanova. Odluka o optimalnom korišćenju gasa između dva ponuđena rešenja može biti doneta na osnovu prostornog rasporeda zgrada, njihovebrojnosti $i$ veličine u okviru pojedinog naselja, itd. Stoga, optimalan izbor između ponuđene upotrebe gasa u širokoj distribuciji domaćinstvima i sistema daljinskog grejanja koji kao primarno gorivo koristi gas (lokalno ili centralizovano sagorevanje gasa) može biti donet primenom metodologije (modelskim pristupom) prikazanim u ovom radu. Model je napravljen tako da obuhvati raznovrsne tipove naselja (u skladu sa veličinom i prostornim rasporedom zgrada) kakva se mogu sresti u Srbiji. Ovaj model predstavlja jednostavan i koristan alat za donošenje inicijalne odluke načinu grejanja

Ključne reči: Prirodni gas, Urbanizam, Distribucija gasa, Centralno grejanje. 